\title{
Employment as a Price or a Prize of Equality: A Descriptive
}

\section{Analysis}

\section{Erling Barth}

Senior Researcher, Institute for Social Research (ISF), Norway

I Karl Ove Moene

Professor, Department of Economics and ESOP, Norway

\begin{abstract}
To put Scandinavian employment in perspective, we ask whether wage compression hampers employment rates, or not. We answer by reviewing the most important theoretical arguments and the most informative regularities across countries with different wage distributions. The pattern seems to be that countries with compressed wage distributions tend to have higher employment, and countries with higher wage inequality tend to have lower employment. This also holds when we consider the rate of labor force participation. In line with the theoretical arguments, coordination in wage bargaining seems to contribute to both employment expansion and wage compression. There is a clear positive correlation between coordination and employment even when we control for inequality, country, and year-specific effects.
\end{abstract}

\section{KEY WORDS}

Employment / Wage Inequality / Social exclusion

\section{Introduction}

quality has both costs and benefits, but there is no agreement on the relative importance of each. Employment is a case in point. Skeptics claim that more wage equality reduces employment by excluding low-productivity workers from employment, which in turn should be considered a high price for equality. Proponents, in contrast, claim that more wage equality, if anything, raises employment by incorporating indirect negative effects in wage setting, implying an employment prize of equality.

Who is right? The answer is of some importance as wages are distributed rather differently in many countries. Figure 1 shows the differences in wage dispersion across countries in 2007. Together with Belgium and Finland, the Scandinavian countries display the most compressed wage structures of all, no matter whether we measure it by the ninth decile to the first $(\mathrm{d} 9 \mathrm{~d} 1)$ or by the median wage relative to the first decile (d5d1).

To see how wage differences like these may affect employment, we first discuss some possible theoretical mechanisms, arguing that the two views on wage equality and

Erling Barth, Senior Researcher, Institute for Social Research (ISF), Norway.

E-mail: Erling.Barth@socialresearch.no 
Figure I: Relative wages, OECD countries 2007.

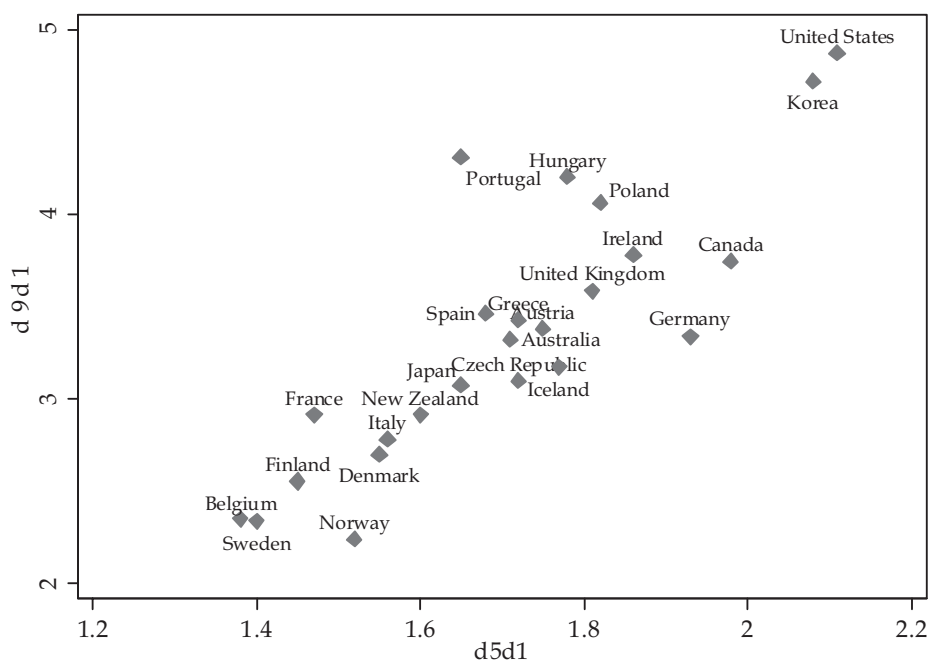

$\mathrm{d} 5 \mathrm{~d}$ I shows median gross earnings relative to the first decile. $\mathrm{d} 9 \mathrm{~d} /$ shows the ninth decile gross earnings relative to the first decile.

Source: OECD iLibrary.

employment might be related to different institutional settings. It is essential how wage compression comes about: whether it is one-sided or two-sided, from below or from below and above. It is also important to account for the presence of employers' monopsony power and whether the wage equality is implemented by unions or by law. Both wage setting systems and welfare state policies can simultaneously affect wage inequality and the supply and demand of labor.

To have a fair battle of theories, one has to get the details right. One decisive detail needs to be considered upfront in order to have a case to discuss: Are wage differentials basically compressed in some countries because the skills distribution is compressed? If that is what we observe, we cannot learn much about the role of wage differentials by comparing countries with different wage distributions - as we do below. There is clear evidence, however, that wage differentials differ across countries, also for a given distribution of observable skills, and even after controlling for the distribution of results on cognitive test scores (Blau and Kahn 2005).

Thus we can use variations across countries and over time to shed light on the role of wage differentials. Yet, we have to recognize the well-known limitations of this kind of analysis as countries differ in many other dimensions in addition to their levels of wage inequality. We can account for some of this heterogeneity by including countryspecific effects capturing country size, history, institutions, local culture, etc. By doing this, we explore how the variations within each country differ across countries. In this first cut our empirical ambitions are therefore modest.

We think of the regressions that we provide as an efficient way of describing the empirical pattern across countries where certain patterns may help us exclude some possible theoretical hypothesis. Thus, we are ready to consider negative correlation between 
wage compression and employment only as an indication that there might be a costly employment price to be paid. Similarly, we consider a positive correlation to be an indication that there is a beneficial employment prize to be obtained. We deliberately use the word indication as we would have to dig deeper in order to establish clear causal relationships.

\section{The battle of theories of employment}

To find out how wage compression affects employment, we need to understand how wage compression comes about. Both skeptics and proponents of wage equality would agree that wage setting systems, union structure, and welfare state arrangements are important, even though they tend to disagree on the partial and overall effects of each factor.

\section{The two views in different settings}

The simplest case for how wage equality may reduce employment is straightforward and convincing. It captures the effects of raising the lowest wages and represents wage compression from below.

\section{One-side wage compression from below}

In general,

i) a high minimum pay requires sufficiently high local productivity for the jobs to be profitable.

Thus, wage compression that raises the lowest wages normally destructs low-productivity jobs as they become economically obsolete. As a consequence, low-qualified persons can be excluded from the employed labor force simply because there is no employer who can profitably employ them. High minimum wages for everybody can in other words make low-qualified persons unemployable.

A simple version of the argument, consistent with the skeptical view on wage compression, might be expressed as follows: The demand for a specific type of low-qualified workers depends on the wage costs for that type of workers - unions raise these wage costs as does a generous welfare state policy; and employment is declining in wage costs, unionization, and the welfare generosity. Wage compression is therefore associated with low employment. Full employment for all types of workers requires a market-based wage flexibility associated with decentralized wage setting, and a not too generous welfare spending.

\section{Compression with monopsony power}

The clear conclusion that wage compression hampers employment may not stand up once we include the possibility that employers may exercise monopsony power in the 
labor market. Recently, the role of monopsony power has been taken more seriously by several leading researchers. It can be particularly important for low-paid groups. Yet, monopsony should not be taken literally as the result of having only one single employer as the local buyer of labor services. Monopsony power may also be a natural result from search frictions that limit the short run mobility among workers across firms and sectors (Card and Krueger 1995, Manning 2003). Wages become sensitive to local labor demand. With search frictions affecting the flows in the labor market, employers may find it profitable to restrict their demand for labor in order to reduce the wage.

Exploiting the monopsony power, the gains to the employer are just the wage reductions, and the costs are the loss of revenue due to lower employment. The strategy is therefore most profitable in low-productivity jobs where the costs of trying to lower wages are lowest. How much the demand for labor is restricted depends on how sensitive wages are to lower demand and how productive the jobs are.

Accordingly,

ii) monopsony power among employers implies that less employment is associated with lower, not higher, wages - and all else being the same employment is held back more in low-productivity jobs than in high-productivity jobs.

With monopsony, the introduction of minimum wages reduces wage inequality by raising the lowest wages at the same time as employment goes up, as employers cannot benefit from reducing their employment below the level that equates marginal productivity to the unit cost of labor. As stated, a partial increase of minimum wages generates both higher equality in the wage distribution and a higher mean wage. Yet, the implications are clear. The effects of a higher minimum wage, either set by unions or in other ways, would show up as a negative correlation between employment and wage inequality.

\section{Two-sided wage compression}

In order to isolate the impacts of wage equality per se, we should focus on two-sided wage compression, i.e., compression from above and from below, allowing for the case of more wage equality for a given mean. In addition, it is important to note that two-sided wage compression has been a pronounced feature of Scandinavian wage policies after World War II. In particular, it is a distinct feature of the so-called solidarity negotiations that became institutionalized in the end of the 1950s in Sweden and Norway.

Some proponents of wage compression build their arguments on two-sided compression, abstracting from monopsony power considerations. An equally simple version of their arguments, as the one we used for the skeptics, might be expressed as follows:

Mean preserving wage compression consists not only of raising the lowest wages, but also of moderating the highest ones. The partial effect of wage moderation at the top is to raise the profitability of firms, inducing further investments in new plants and equipment, stimulating employment and making it possible to raise the lowest wages without increasing unemployment (Moene and Wallerstein, 1997). 
Wage compression can in this manner reduce non-competitive wage differentials across plants, also for workers of the same skills. By cutting the level of rent sharing, the elimination of non-competitive wage differentials stimulates investment in new technology. Technologically advanced and high-paying firms may as a result pay lower wages, while low-productivity and low-paying firms have to pay higher wages, compared with a situation without wage compression. In short,

iii) two-sided wage compression fuels a positive structural change - low-productivity jobs are destructed and high-productivity jobs are created.

Hence, two-sided wage compression does not only reduce the ability of low-productive firms to remain in business with their old technology but also increase the ability to establish more high-productivity jobs. It simply speeds up the process of creative destruction, leading to a new path where the gap between the most and the least productive plants becomes smaller.

In sum, wage restraints at the top imply that the wage of the least qualified workers can be raised without reducing their employment. Accounting for how the employment of each type of workers may depend on the wages to all types of workers employed, wage equality is therefore not associated with declining, but rather with expanding employment rates.

If this sketch is a fair representation of the core mechanism in the two views, the controversy boils down to what unions actually do when they compress wages.

\section{What do unions do?}

Are unions compressing the wage structure only by raising the bottom wages? Or, are unions compressing the wage structure from both the top and the bottom? How does the presence of unions affect monopsony power of employers? And, how does the system or level of coordination of wage setting affect wage compression by unions?

Unfortunately, there is no theoretical consensus on what unions actually do, not to mention what unions maximize, if anything. Overviews are provided by, for instance, Freeman and Medoff (1984) and Moene et al. (1993). There is neither a consensus about what the typical wage contract covers. Is it just the wage levels, or both wages and employment levels? In the following discussion, we apply a convention favoring the skeptical view on wage compression.

We think of unions as quasi-democratic institutions that care about their members' real wages and employment levels. In short, unions care about both pay and jobs. In addition, we think of the wage contract as an agreement that covers only wages, leaving the right to manage employment levels to the employers.

Each union balances its assessment of the raise in material well-being that a higher wage level would generate, against the reduction in well-being of others who might lose their jobs at a higher wage level. In this calculation, the material well-being is measured by the consumer real wage, reflecting the material well-being workers can acquire by their nominal wages (nominal wages divided by the consumer price index). The gain of a wage increase, measured in this way, must be traded-off against the direct - and perhaps also the indirect - job loss. 


\section{Direct and indirect job losses}

The rise in the product real wage (the nominal wages divided by the relevant prices that employers obtain in output markets) may imply job losses - as principle (i) applies. As employers to some extent can pass on wage increases to the prices they charge in accordance with their market power, the product real wage may increase less than the consumer real wage. What we denote the effective monopoly power of the union measures the ability of the union to raise its consumer real wage without a proportional increase in its product real wage. A high ability to limit the rise in the product real wage also limits the direct job loss, the punishment for higher wages.

Jobs can also be lost if higher wages reduce profits and in turn profit-induced investments, with detrimental effects on the creation of new jobs. Declining investments may affect the demand for all types of workers, not only the particular workers whose wage is changed.

The effective monopoly power and indirect job losses constitute important externalities in wage setting. Hence, higher wages to one group may influence the employment of all groups of workers. When all unions raise their wages by say ten percent, the consumer real wage goes up with ten percent, even though all unions may calculate with a much lower impact from their own wage increase. The indirect job loss is another source of externality. A wage increase may hamper the demand for other types of workers via lower profit-induced investments.

Faced with externalities that arise via real wages and employment levels, each union leader is similar to a car owner in the rush hour who, deciding whether to drive or not, only considers his own expected time in the traffic jam and disregards how his driving contributes to the total traffic jam. Just as each car driver has reasons to neglect that it is the total car driving by all drivers that actually makes the traffic jam, each union has reasons to disregard the total impacts of higher wage demands by all unions.

\section{Unions, monopsony, and fairness}

To find the impact of unions and wage coordination, we also have to return to the possibility that employers can exercise monopsony power. Employers are restricted in their exercise of monopsony power when they face a local union that represents the collective interests of the local workforce, making it less profitable to restrict employment. Thus, union wage setting might have similar implications to an exogenously set minimum pay. The employers cannot gain as much as before by reducing his employment levels in the hope of raising profits by reducing the equilibrium wage - just as principle (ii) implies.

In addition, unionization means a change in how the relative wages are determined among union members. Collective bargaining means that each union now bargains on behalf of all its members who might have different earning capacities. Collective bargaining means that some worker-employer bargaining is replaced by worker-worker arguing. Hence, it becomes more difficult to utilize the same type of industrial actions in worker-worker encounters as in worker-employer encounters.

Most likely notions of fairness, such as "equal wage for equal work," receive a more prominent place in the determination of relative wages as the ability to apply brute 
bargaining force declines. As the incidence of collective bargaining increases, the possibility of employers to reward individual workers declines. Thus, employers' ability to discriminate between similar workers, who nevertheless may have different productivity, may vanish. Wages have to reflect some kind of average productivity and collective bargaining would thus almost by definition represent an implicit two-sided compression from below and above - in accordance with principle (iii).

Yet, since this compression takes place within the bargaining unit, there might be differences across countries that stem from variations of the size and composition of bargaining units between countries. These variations of the size and composition of bargaining units depend on the level of wage coordination.

\section{Bargaining coordination}

Wages can be coordinated within each company or firm only, across firms within the same industry, or between firms and industries across the entire nation. The implications are rather clear cut: Wages are compressed over the bargaining unit. Thus, when wages are determined at the firm level, unions compress the distribution of wages within the firm. When wages are set at the industry level, unions compress the distribution of wages across firms within the industry. When wages are set at the national level, unions compress the distribution of wages across firms, industries, and occupations throughout the entire nation.

The gains from coordination tend to be distributed according to fairness norms. The resulting pattern is therefore that more coordination is associated with less wage inequality, implying that the level of wage coordination determines both the size of the gains and the units over which the fairness norms are applied.

Part of the coordination gains from unionized labor markets is a reduction of the possibility of employers to excise monopsony power over low-paid workers. The isolated impacts are to raise both wages and employment. Hence, by raising these low wages, equality goes up together with employment levels. Further coordination across firms weakens employers' monopsony power even more.

Moving wage coordination from the firm level to the industry level means that the union association becomes stronger as it is more comprehensive and organizes all competing workers. The association would therefore be able to pose more aggressive wage demands as its effective monopoly power would increase. Yet, the association would not be comprehensive enough to internalize all externalities in wage setting. The result is therefore a higher average wage, reduced profitability, and lower investment. The decline in investments is in turn likely to reduce the demand for other types of workers. All in all, the end result might be more wage equality and lower employment.

Further coordination, across industries and across different types of workers, has different implications. It implies that the wage setting would be coordinated between workers who are complements in total production, implying that the demand for all workers involved would move in tandem. Coordination of wage setting among workers who are complements therefore leads to wage moderation and employment expansion. The highest wages are held back more than the lowest wages. In addition, all coordination across industries reduces the ability of union leaders 
to pass on higher wage costs to market prices for goods that their members do not consume.

Paradoxically, therefore, a strong and comprehensive union association has less effective monopoly power than a less comprehensive association. Wage moderation results since coordination in wage bargaining internalizes more of the externalities including the total employment effects of wage restraint. ${ }^{1}$

If all this is right, the variation created on employment and wage inequality by altering the level of coordination is not monotonic. Starting from a low level, more coordination tends to yield higher wage inequality and less employment. Further coordination, however, implies more wage equality and higher employment levels. There might also be grey areas of more mixed results depending on the presence of monopsony power and on which groups coordinate their wages - whether coordination takes place among high- or low-paid workers.

\section{The message}

The clearest message from our theoretical review is the importance of distinguishing between one-sided and two-sided wage compression. While wage compression from below is likely to reduce employment, wage compression from both sides is likely to increase employment. In addition, monopsony may matter. If compression is associated with less exercised monopsony power, we expect a positive correlation between employment and wage equality.

So again, it is important how wage inequality in fact is reduced - whether it is through union bargaining that only sets a floor on the lowest wages or whether it is through wage coordination across unions that raises the bottom and restrains the top. Or is more wage equality basically a result of other interventions that curb the exercised monopsony power of employers?

In addition, we need to consider how wage equality affects the supply of labor and in particular the discrete choice whether to participate, or not, in the active labor force. When lowest wages are raised, all else being the same, one should expect a stronger willingness to participate in the labor force by people with low qualifications, irrespective of whether the compression is one sided or two sided.

Let us now turn to what the data can tell us. We use data on employment, labor market attachment, unemployment, and wage inequality from 22 countries over 22 years, ${ }^{2}$ for the most part obtained through the Organization of Economic Cooperation and Development (OECD).

\footnotetext{
${ }^{1}$ A related issue has been studied in the literature, emphasizing how the relationship between successive coordination and the wage demands by workers is likely to be first increasing and then decreasing. Calmfors and Driffill (1988), Freeman (1988), and Moene et al. (1993) argue that the relationship between centralization and economic performance is hump-shaped rather than monotonic. According to their view, countries with either highly centralized or decentralized wage setting should do better than those in an intermediate position. But the empirical support for the hump shape is not crystal clear.

2 See Appendix I for a detailed description of the data.
} 


\section{Employment population rates}

As is apparent from the discussion above, it is likely that there are several mechanisms at play at the same time. We are unable to provide a causal analysis of the relative impact of each of these mechanisms. What we do provide, however, is a descriptive analysis of the empirical relationship between the two variables along various cuts and dimensions.

Our argument is simple: If the relationship between wage equality and employment rates, conditional on various other factors, remains positive, the mechanisms underscored by the skeptics are either empirically not present or not strong enough to determine employment rates. Furthermore, if the arguments of the skeptics dominate empirically, we expect higher sensitivity to equality, particularly among marginal groups in the labor market. We organize the bits and pieces of evidence in separate descriptive claims.

\section{Employment is not lower in countries with high equality}

We use the employment population ratio as a measure of labor demand. If the skeptics toward equality are right, we expect to find a positive correlation between wage inequality and employment rates. If the skeptics are right, however, we expect to find that marginal groups, groups with lower skills and wages, have relatively lower employment rates in countries with a compressed wage structure. These are the groups that should face poorer employment opportunities when wages at the bottom of the distribution are too high.

As a first illustration, consider 2007, the last year before the financial crisis. How the different economies dealt with the crisis and recovery may show up in employment and wages in ways that are highly interesting, but that may be unrelated to the more basic discussion of wage equality and employment. The description of the OECD countries given below shows a rather robust pattern where employment rates are particular high in the Scandinavian countries with the smallest wage differences. The data we use are described in the appendix, where we also provide a set of summary tables for all the OECD countries.

\section{Vulnerable age groups are not underemployed}

Consider first the employment rates of various demographic groups with different levels of labor market attachment: Youth and the elderly of both sexes, and the overall employment rate of men and women between 15 and 64 years. Figure 2 shows the employment rates for a few countries as an illustration. We have picked the USA and the UK as representing the most flexible relative wage regimes; France, Spain, and Italy as representing the middle ground; and the Scandinavian countries as representing the wage-compressed regime. The numbers for all countries are reported in Appendix Table A1.

Figure 2 shows on the $x$-axis the OECD average employment ratio for the different demographic groups. The young have the lowest employment rates. On the $y$-axis we show the performance of the different countries. Points above the $45^{\circ}$ line show countries with above-average employment rates, and points below show countries below the 
Figure 2: Employment-population ratios, demographic groups.

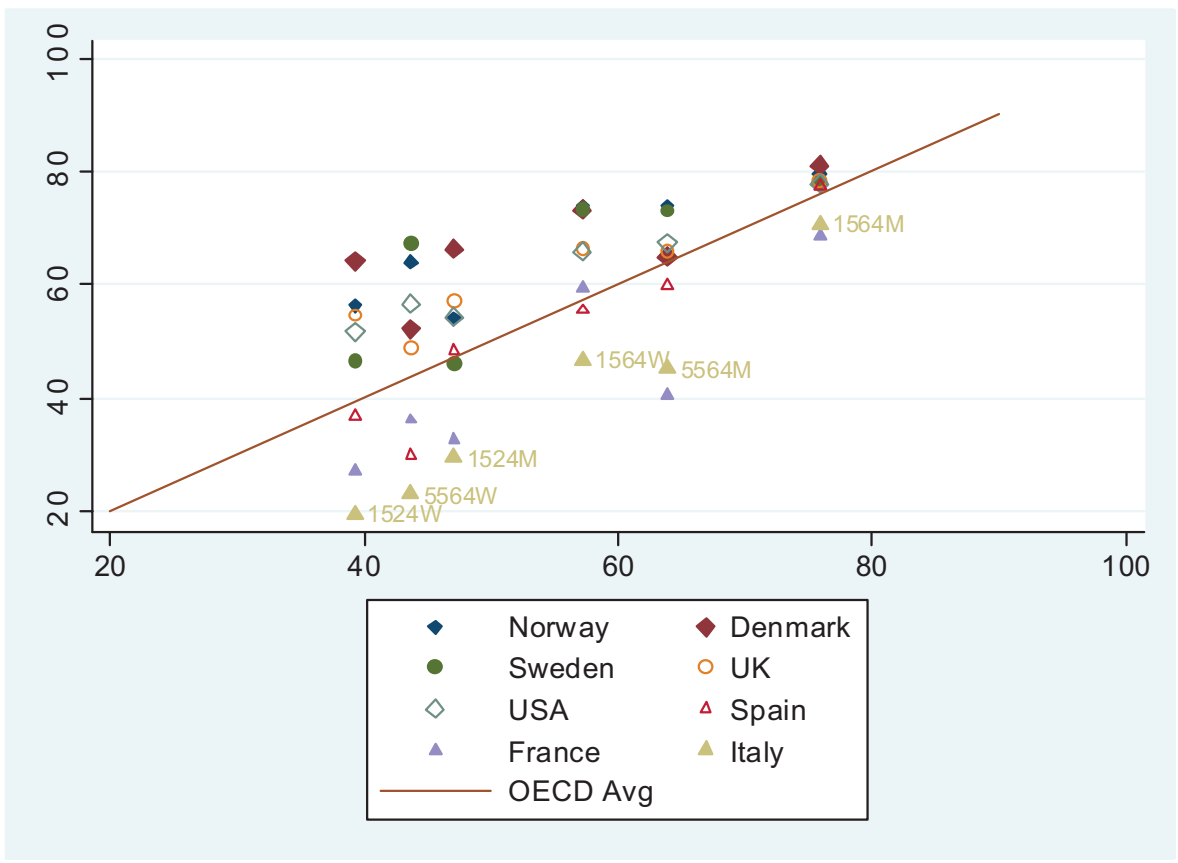

Source: OECD Labor Force Statistics, see Appendix Table A I.

average. We find the Scandinavian countries at the top, together with the USA and the UK, with France, Spain, and Italy below the average (see also Faggio and Nickell, 2006). Even among the groups with lower labor market attachment, the wage-compressed countries score very high.

Employment rates for young people are affected by the number of students. In countries with high educational attainment, employment-population rates are lower. We have thus calculated employment rates for young people who do not report studying as their main activity. Figure 3 shows employment rates both for young men (20-24 years of age) and for those who are not students, using data from the European Social Survey. We find Norway high up, with employment rates above 70 percent for young men and with close to 90 percent for non-students. Denmark and Sweden have high numbers as well. Even though these numbers are taken from smaller surveys than the labor force surveys used by the OECD, and the numbers are thus more uncertain, the picture is clear: The employment rates of the Scandinavian countries are very high, even for youth. The figures for young women (not shown) are even more striking.

\section{Workers with low education seem not to be excluded}

Figure 4 shows similar figures of employment rates as figure 2, but now for individuals with less than upper secondary schooling, upper secondary schooling, and tertiary 
Figure 3: Employment rates for young and for non-students.

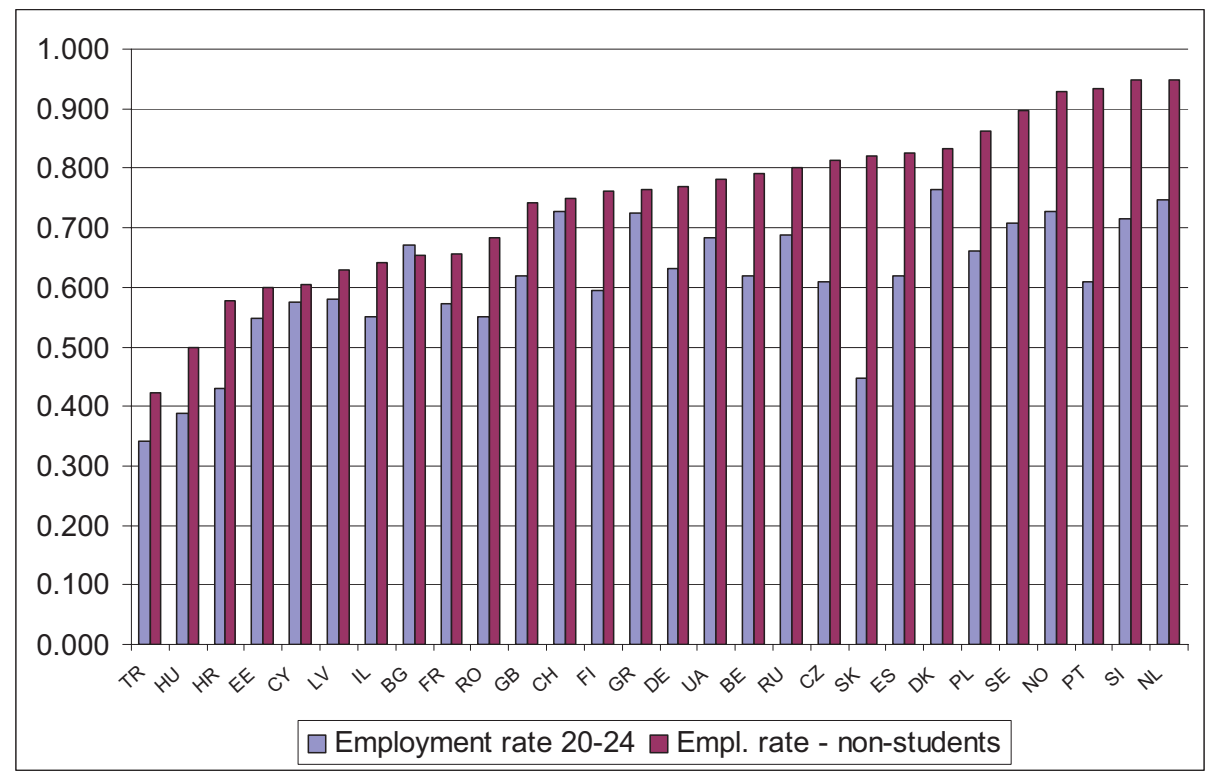

Source: Own calculations on European Social Surveys, 2008. Non-students are defined as persons in the relevant age group who do not report studying as their main activity.

Figure 4: Employment-population ratios, levels of education.

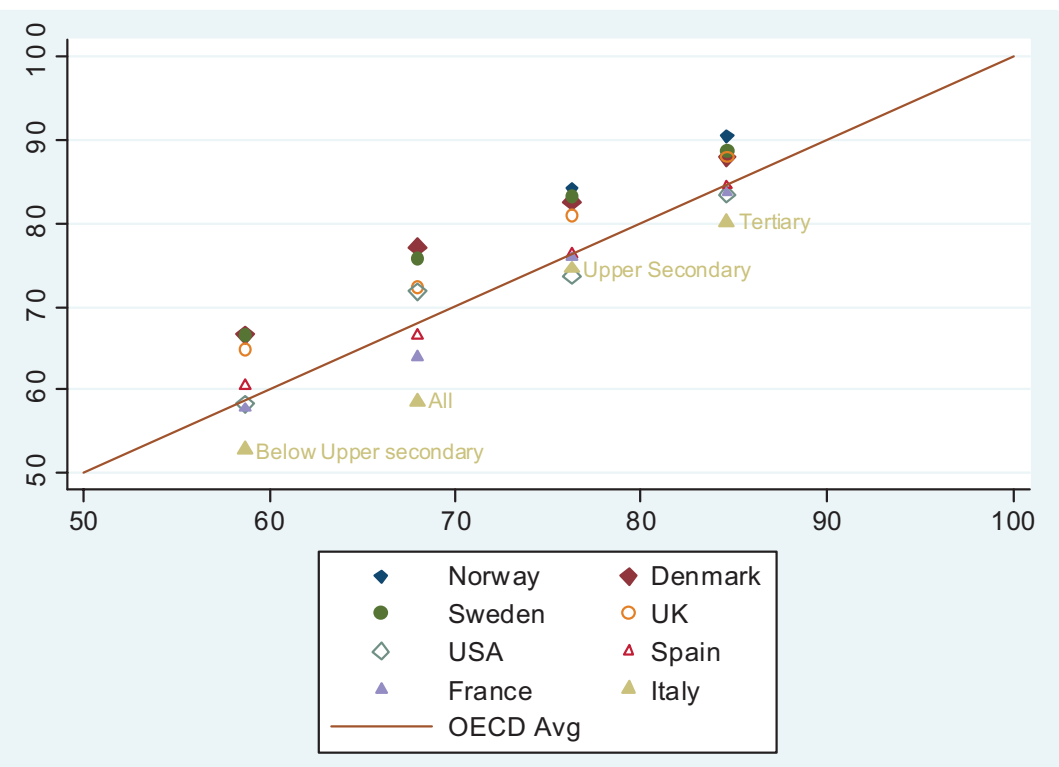


schooling. Figures for all the OECD countries are reported in Appendix Table A2. Looking at Figure 4, we find that the employment rates are rising in the level of education. Again, we find the Scandinavian countries among the top in all categories, even in the groups with the lowest level of education (below upper secondary schooling).

\section{Relative employment rates are also high where equality is high}

These figures are striking. However, a host of different factors may influence employment rates, other than relative wages. In this section, we present figures for relative employment rates instead of absolute rates. Consider first the demographic groups. Table 1 provides the ratio of the employment rate of a given group relative to the employment rate of prime age males in the same country; this relative measure may provide a more relevant test of the hypothesis that relative wages affect relative employment. Among all groups, the Scandinavian countries have higher relative employment rates than the OECD average, and for most groups, the numbers are also higher than for the flexible relative wage countries, the UK and the USA. The exception is Swedish young men, who have low relative employment ratio.

We do the same exercise for educational groups, now measuring the employment rates of low-skilled workers relative to high-skilled workers. The figures are given in Table 2. The pattern here is clear. The Scandinavian countries have at least as high relative employment rates as the USA and the UK. For low education, the relative employment rates are considerably higher than the OECD average.

We have so far made comparison across countries in one year - 2007. This may be a peculiar year, and the pattern may look different at other times, for instance if the different countries react differently to the business cycle. Let us thus now turn to a comparison of employment patterns over time across a panel of countries.

Table I Relative employment rates for different demographic groups, 2007.

\begin{tabular}{lcccccc}
\hline & \multicolumn{3}{c}{ Relative employment rate relative to prime age men } & \multicolumn{2}{c}{ Empl./pop. \% } \\
\cline { 2 - 7 } & Men 1524 & Men 5564 & Women 1524 & Women 5564 & Women 2554 & Men 2554 \\
\hline Denmark & 0.74 & 0.72 & 0.7 I & 0.58 & 0.9 I & 90.2 \\
\hline Norway & 0.61 & 0.83 & 0.63 & 0.72 & 0.92 & 89.2 \\
\hline Sweden & 0.52 & 0.82 & 0.52 & 0.75 & 0.93 & 89.0 \\
\hline The USA & 0.62 & 0.77 & 0.59 & 0.65 & 0.83 & 87.5 \\
\hline The UK & 0.65 & 0.75 & 0.62 & 0.55 & 0.85 & 88.3 \\
\hline OECD avg & 0.54 & 0.73 & 0.45 & 0.50 & 0.75 & 88.0 \\
\hline France & 0.37 & 0.46 & 0.31 & 0.41 & 0.86 & 88.3 \\
\hline Spain & 0.55 & 0.68 & 0.42 & 0.34 & 0.75 & 87.6 \\
\hline Italy & 0.34 & 0.52 & 0.22 & 0.26 & 0.68 & 87.3 \\
\hline
\end{tabular}

Source: OECD Labor Force Statistics, extracted from the OECD ilibrary. 
Table 2 Relative employment rates by educational group (25-64), 2007.

\begin{tabular}{lccc}
\hline & Low & Medium & Tertiary \\
\cline { 2 - 4 } & Relative employment rate relative to tertiary & Empl. pop. \% \\
\hline Denmark & 0.76 & 0.94 & 87.8 \\
\hline Norway & 0.73 & 0.93 & 90.4 \\
\hline Sweden & 0.75 & 0.94 & 88.6 \\
\hline The USA & 0.70 & 0.88 & 83.3 \\
\hline The UK & 0.74 & 0.92 & 87.8 \\
\hline OECD avg & 0.69 & 0.90 & 84.6 \\
\hline France & 0.69 & 0.91 & 83.5 \\
\hline Spain & 0.72 & 0.90 & 84.4 \\
\hline Italy & 0.66 & 0.93 & 80.2 \\
\hline
\end{tabular}

Source: OECD Labor Force Statistics, extracted from the OECD ilibrary.

Table 3 Employment population rates, 15-64 years, percent.

\begin{tabular}{lccc}
\hline & $\begin{array}{c}\text { Model I } \\
\text { b/se }\end{array}$ & $\begin{array}{c}\text { Model 2 } \\
\text { b/se }\end{array}$ & $\begin{array}{c}\text { Model 3 } \\
\text { b/se }\end{array}$ \\
\hline Wage inequality $(\ln \mathrm{d} 9 \mathrm{dI})$ & $-0.1089 * * *$ & $-0.0938 * *$ & -0.259 |***** \\
\hline Year dummies & $(0.024 \mathrm{I})$ & $(0.03 \mid 8)$ & $(0.0405)$ \\
\hline Covariates & Yes & Yes & Yes \\
\hline Fixed country effects & & Yes & Yes \\
\hline$N$ & 322 & 322 & Yes \\
\hline
\end{tabular}

Note: Dependent variable, In(employment population rate, ages I5-64 years). Number of countries, 22. Years: 1985-2007. Covariates include the share of tertiary education, an index of employment protection, the tax wedge, public expenditures on active labor market measures, union density, and public social expenditures. Level of significance (****) I pct, (***) 5 pct, and $(*)$ I0 pct. See Appendix I for details on the data.

\section{Panel analyses confirm the negative relationship between employment and inequality}

We use observations from the 22 countries over more than 20 years to check if the main impression from the cross-country comparison above is maintained when including a host of controls that may influence employment rates. We use simple regression models of employment rates on wage inequality, including both year and country fixed effects. A positive coefficient for wage inequality suggests that the skeptics are right, whereas a negative coefficient shows that the main pattern displayed above is maintained.

Table 3 provides the results. The dependent variable is $\ln$ (employment population ratio). The first column shows a specification with year dummies only. The elasticity of employment with respect to wage inequality is measured to -0.1 , displaying a negative 
pattern. In model 2, we add several covariates to the analysis: the share of tertiary education, an index of employment protection, public expenditures on active labor market measures, union density, the tax wedge, and public social expenditures. ${ }^{3}$ The coefficient is still negative at -0.09 .

A host of country-specific factors may affect both employment rates and wage inequality. In model 3, we show that the negative relationship between wage inequality and employment rates shows up even when we identify the relationship based on within-country differences only, including control for the other covariates. The elasticity is now measured to -0.26 . Note that this relationship is estimated using within-country variation in wage inequality, and all constant country-specific attributes, such as history, climate, or natural resources, are swept out of the analysis.

\section{Coordination of bargaining is associated with higher employment}

As discussed, both bargaining coordination and high levels of welfare generosity may induce wage compression (see Barth and Moene 2011). In this section, we introduce measures of both into the regression framework in order to check if the observed relationship between wage inequality and employment rates mainly arises from the underlying institutional factors or from wage compression per se.

Table 4 reports the regression models for a sample of country years where we also have reliable measures of welfare generosity and bargaining coordination (Sample 2

Table 4 Employment population rates, 15-64 years, percent. Smaller sample.

\begin{tabular}{|c|c|c|c|}
\hline & $\begin{array}{c}\text { Model I } \\
\text { b/se }\end{array}$ & $\begin{array}{c}\text { Model } 2 \\
\text { b/se }\end{array}$ & $\begin{array}{c}\text { Model } 3 \\
\text { b/se }\end{array}$ \\
\hline \multirow[t]{2}{*}{ Wage inequality In d9dI } & $-0.2533 * * * *$ & $-0.1948 * * * *$ & -0.0896 \\
\hline & $(0.0655)$ & $(0.0661)$ & $(0.0679)$ \\
\hline \multirow[t]{2}{*}{ Welfare generosity } & & & $0.178 \mid$ *** \\
\hline & & & $(0.0645)$ \\
\hline \multirow[t]{2}{*}{ Bargaining coordination } & & & $0.0392 *$ \\
\hline & & & $(0.0157)$ \\
\hline Year dummies & Yes & Yes & Yes \\
\hline Covariates & Yes & Yes & Yes \\
\hline Fixed country effects & & Yes & Yes \\
\hline$N$ & 178 & 178 & 178 \\
\hline
\end{tabular}

Note: Dependent variable, In(employment population rate, age 15-64 years). Number of countries, 14. Years: 1985-2002. Covariates include the share of tertiary education, the tax wedge, an index of employment protection, public expenditures on active labor market measures, union density, and public social expenditures. Level of significance (*****) I pct, (**) 5 pct, and (*) 10 pct. See Appendix I for details on the data.

\footnotetext{
${ }^{3}$ Most of the data are extracted from the OECD ilibrary. See Appendix 1 for details.
} 
of 14 countries from 1985 to 2002, see data appendix for details). We first establish that there is also a negative correlation in these data. When we introduce country fixed effects, the coefficient for wage inequality becomes smaller, but it is still highly significant. In model 3, we find that both welfare generosity and bargaining coordination show up with positive coefficients. Both of these institutions have a wage compressing effect, and some of the negative correlation between wage inequality and employment is due to this effect. The coefficient for wage inequality has dropped by one-half, but remains negative, even though it is no longer statistically significant. The results clearly offer no support to the view that wage compression is detrimental to employment.

The results confirm a positive relationship between bargaining coordination and employment, as we would expect, and a more surprising positive relationship between welfare generosity and employment. Note, however, that these results reflect partial correlations and need not have a causal interpretation.

\section{Labor force participation rates and unemployment}

Does equality lead to low labor force participation? We offer a description that indicates that there is a positive relationship between wage equality and participation. Hence, contrary to the skeptics' views, mechanisms that induce more equality seem not to prevent people from participating in the formal work. Or, in other words, the circumstances that benefit wage equality do not seem to directly hamper labor force participation.

\section{Participation rates are not lower in countries with high equality}

High employment rates show that employers are willing to employ a large part of the population at any given time. Another requirement is that a large part of the population is willing to work under the current conditions. The skeptics of equality would argue that a compressed wage structure, in particular arising from a generous welfare state, would limit labor supply. This effect should be most pronounced for groups that are at the margin of labor force attendance, especially at the bottom of the wage distribution. The defenders would argue that a compressed wage structure provides people with incentives to work, especially at the bottom of the wage distribution, since this is where wages are higher. As we show below, it turns out that labor supply is high in countries with low wage dispersion.

\section{Participation rates for vulnerable groups are also high in countries with high equality}

Table 5 shows that participation is high in Scandinavia also for sub-groups. However, the numbers are not as distinct for all the different groups as they were for employment. In particular, the number for prime age men, an average of 92.1 for the Scandinavian countries, is slightly below the average for EU 15 of 92.8 . Still, this difference is hardly sufficient to substantiate a claim that wage inequality or the welfare state of the Scandinavian countries limits labor supply. The labor supply of the young, and the old, is among the top in the OECD. 
Table 5 Labor market participation for different demographic groups, 2007.

\begin{tabular}{|c|c|c|c|c|c|c|}
\hline & \multicolumn{5}{|c|}{ Participation rates relative to prime age men } & \multirow{2}{*}{$\begin{array}{c}\text { Part./Pop } \\
\text { rate } \%\end{array}$} \\
\hline & Men 1524 & Men 5465 & Women 1524 & Women 5564 & Women 2554 & \\
\hline Denmark & 0.78 & 0.72 & 0.75 & 0.59 & 0.92 & 92.5 \\
\hline Norway & 0.65 & 0.82 & 0.66 & 0.71 & 0.92 & 90.9 \\
\hline Sweden & 0.61 & 0.82 & 0.62 & 0.75 & 0.94 & 92.9 \\
\hline The USA & 0.68 & 0.77 & 0.63 & 0.64 & 0.83 & 90.9 \\
\hline The UK & 0.74 & 0.75 & 0.68 & 0.55 & 0.85 & 91.6 \\
\hline OECD avg & 0.58 & 0.72 & 0.48 & 0.49 & 0.76 & 92.2 \\
\hline France & 0.43 & 0.45 & 0.36 & 0.40 & 0.88 & 94.2 \\
\hline Spain & 0.62 & 0.68 & 0.51 & 0.35 & 0.78 & 92.6 \\
\hline Italy & 0.40 & 0.51 & 0.28 & 0.26 & 0.70 & 91.0 \\
\hline
\end{tabular}

Source: OECD Labor Force Statistics, extracted from the OECD ilibrary

Table 6 shows results from similar regression models of labor force participation as we used for employment. We find very similar results to those concerning employment, with somewhat smaller coefficients for wage inequality. However, while bargaining coordination was correlated with employment, this is not the case for participation. Welfare generosity, in contrast, is clearly positively correlated with labor force participation rates.

The coefficient for wage inequality is somewhat smaller than it was for employment rates, but it is still significantly negative and rather large in size. The last bottom column shows that there is a negative, but not statistically significant relationship between labor supply and wage inequality, conditional on bargaining coordination and welfare generosity even when identified using within-country variation only.

\section{High participation and low wage inequality are not associated with high unemployment}

One could think that high participation in the labor force would create high unemployment unless wages are flexible and unequal enough to generate full employment. Yet, in spite of Scandinavian wage compression and perhaps lower flexibility, both the overall unemployment rates and those for different demographic groups are lower in Scandinavia than in most other countries (see, e.g., Nickell et al. 2005 and Faggio and Nickell, 2006). The exception to this pattern is young people in Sweden who experience very high unemployment rates (Figure 5). Table A4 in the appendix gives numbers for all OECD countries.

\section{Relative unemployment rates indicate that Scandinavia is more similar to other countries}

When we look at relative unemployment rates, for instance, the rate of young unemployed to the rates of prime age men, the picture is more mixed. Table 7 reports the 
Table 6 Labor force participation rates 15-64 years.

\begin{tabular}{|c|c|c|c|c|}
\hline \multicolumn{5}{|l|}{ Without fixed country effects } \\
\hline \multirow[t]{2}{*}{ Wage inequality (In d9dI) } & -0.0276 & $-0.1995 * * * *$ & & $-0.2006 * * * *$ \\
\hline & $(0.0274)$ & $(0.0558)$ & & $(0.0726)$ \\
\hline \multirow[t]{2}{*}{ Welfare generosity } & & & $0.1668 * *$ & $0.1288 *$ \\
\hline & & & $(0.0673)$ & $(0.067 \mid)$ \\
\hline \multirow[t]{2}{*}{ Bargaining coordination } & & & 0.0100 & -0.0070 \\
\hline & & & $(0.0078)$ & $(.0096)$ \\
\hline \multicolumn{5}{|l|}{ With fixed country effects } \\
\hline \multirow[t]{2}{*}{ Wage inequality (In d9dI) } & $-0.1296 * * * *$ & $-0.1000 * *$ & & -0.0404 \\
\hline & $(0.027 \mathrm{I})$ & $(0.0466)$ & & $(0.0482)$ \\
\hline \multirow[t]{2}{*}{ Welfare generosity } & & & $0.1586 * * * *$ & 0.1540 ***** \\
\hline & & & $(0.0453)$ & $(0.0457)$ \\
\hline \multirow[t]{3}{*}{ Bargaining coordination } & & & 0.0181 & 0.0150 \\
\hline & & & $(0.0105)$ & $(0.0|| 2)$ \\
\hline & 1985-2007 & & 1985-2002 & \\
\hline \multicolumn{5}{|l|}{ Years } \\
\hline \# of countries & 22 & & 14 & \\
\hline$N$ & 322 & & 178 & \\
\hline
\end{tabular}

Note: Dependent variable: In(participation rate). All models include control for fixed year effects, the share of tertiary education, the tax wedge, an index of employment protection, public expenditures on active labor market measures, union density, and public social expenditures. Level of significance (***) I pct, (**) 5 pct, and (*) 10 pct.

results. Now we find that the Scandinavian countries look more like the USA and the UK and have higher relative unemployment rates than the OECD average.

Turning to an educational grouping, the picture switches back to one that is favorable for the Scandinavian model. The unemployment ratios between high and low education are favorable for high education groups, and there is more variation between the Scandinavian countries in unemployment rates. Perhaps surprisingly, all the Nordic countries have a smaller ratio between the unemployment rates of low-educated workers and high-educated workers than both the USA and the UK, countries with high wage inequality and flexible wages (Table 8).

\section{Concluding remarks}

Above, we have focused most on the link from wage equality to employment. We do not find indications in the data that low employment rate constitutes the price of wage equality. On the contrary, our descriptive analysis indicates that there is a positive and robust association between wage equality and employment: a prize of wage equality. This pattern in the data seems inconsistent with the assertion of the skeptics that wage 
Figure 5: Unemployment rates, demographic groups.

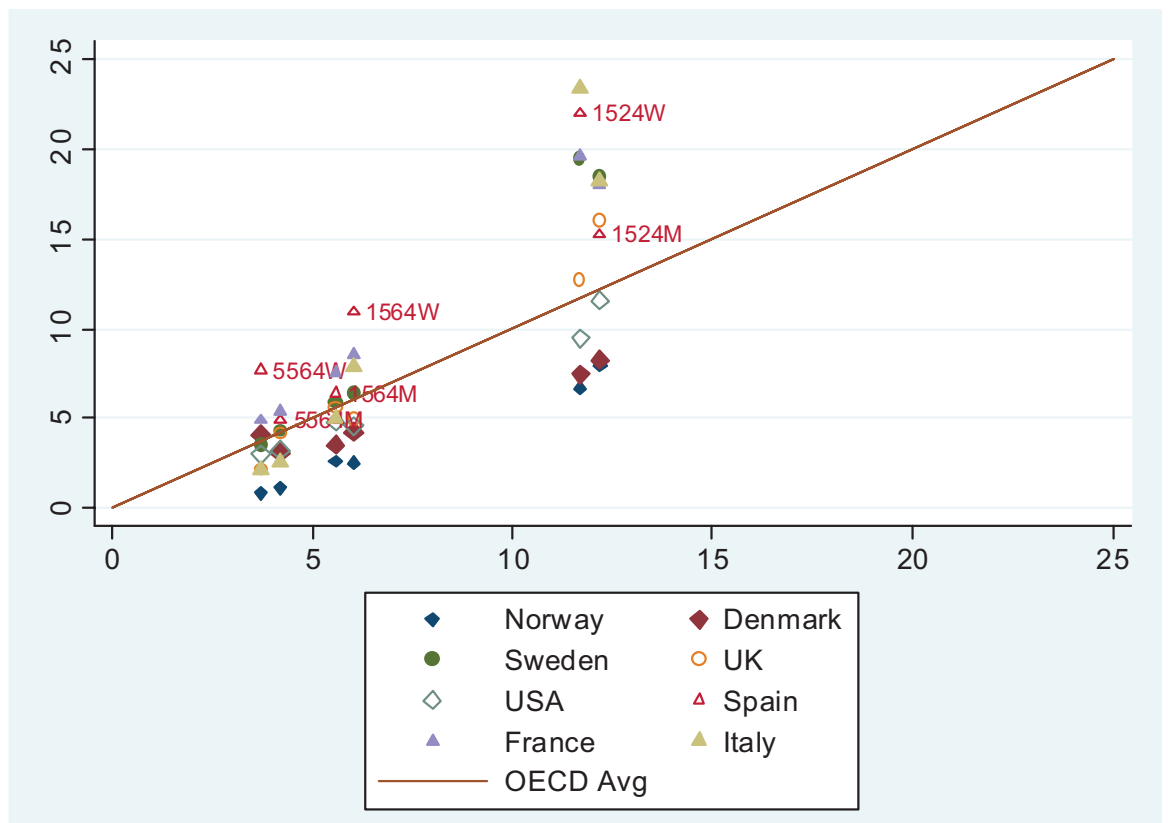

Table 7 Relative unemployment rates for different demographic groups, 2007.

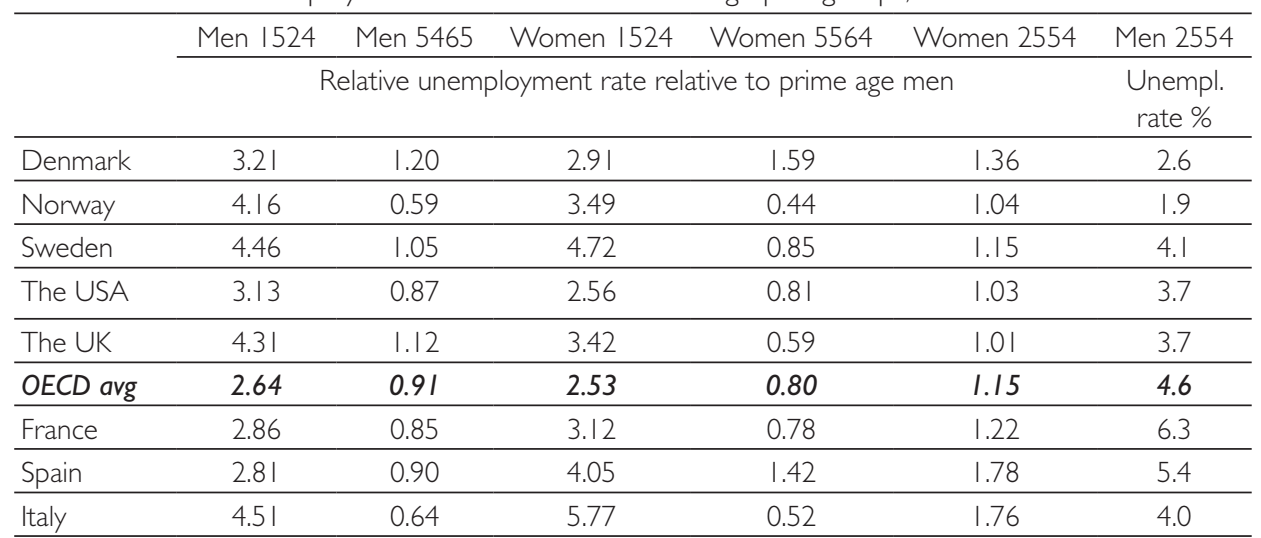

Source: OECD Labor Force Statistics, extracted from the OECD ilibrary.

compression forces low-paid workers out of their jobs and eventually over to welfare programs.

Throughout we have emphasized that the regression models presented above are descriptive. Causation is a separate issue and it can go both ways. Consider the 
Table 8 Relative unemployment rates, lower versus tertiary, ratio 2007.

\begin{tabular}{lccc}
\hline & Lower/Tertiary & Upper Secondary/Tertiary & Tertiary u-rate \% \\
\hline Denmark & 1.42 & 0.86 & 2.95 \\
\hline Norway & 2.33 & 0.93 & 1.40 \\
\hline Sweden & 2.07 & 1.25 & 3.37 \\
\hline The USA & 4.01 & 2.14 & 2.11 \\
\hline The UK & 2.86 & 1.74 & 2.27 \\
\hline OECD avg & 2.62 & 1.44 & 3.40 \\
\hline France & 2.11 & 1.23 & 4.86 \\
\hline Spain & 1.87 & 1.42 & 4.81 \\
\hline Italy & 1.51 & 0.99 & 4.18
\end{tabular}

Source: OECD Labor Force Statistics, extracted from the OECD ilibrary.

following simple example where employment rates become higher for some unobserved reason, say high international demand for the country's goods. In that case, marginal workers are pulled into the labor force, and since they are likely to be pulled from the lower end of the skills distribution, their inclusion affects the wage distribution. In other words, in this case the wage distribution is determined by the employment rate and not vice versa.

This reverse causality is of course a possible story. Note, however, that if this is the case, we would expect a positive relationship between wage inequality and employment, and not the negative effect that we have found. An ordinary least square regression in the case of an endogenous regressor comes up with an estimator that is a weighted average of the two effects. So what we have found is an attenuated measure, not an exaggerated one: What we have provided in that case is a conservative measure of the effect of wage inequality on employment. Of course, it is possible to construct other stories that would support a causal relationship going from employment to wage dispersion, and we do not claim that our results are able to sort these out. All in all, we are thus reluctant to conclude strongly with respect to the mechanisms that drive our results.

We have also demonstrated some further regularities, or correlations, that are worth considering. For instance, we find a positive correlation between the generosity of the welfare state and labor force participation. This is contrary to what many people think. With the link between participation and employment, it may also have clear implications for the association between welfare generosity and employment.

Here we can only speculate about the possible causes for the positive associations. One thought is that the design of the welfare state favors people with a job. To have a job gives them rights to future benefits. In addition, higher minimum wages give people incentives to work, even when the welfare state provides a generous floor. In the Scandinavian countries, eligibility and the generosity of social insurance and welfare benefits are to a large extent conditioned on labor income. Social insurance benefits thus actually add to the value of the wage, in particular for groups with higher risk. Examples are disability benefits, unemployment benefits, and maternity leave, all adding to work incentives. In sum, the Scandinavian welfare states have for long practiced rules that tie welfare benefits to having (had) a job ("arbeidslinjen"), implying that the 
generosity of the welfare state may also provide strong incentives to participate in the labor market.

Also, high employment levels are more important for the politics of the welfare state than it is for economies where a larger part of social insurance is provided inside the family. This may perhaps be why we see such a strong focus on activation policies and activation measures in social policy in the countries where the risk is diffused through a public insurance system rather than through the family system.

Another thought is that there might be a reverse causality between generosity and labor force participation. It might not be a generous welfare state that fuels labor participation, but rather the high employment rates that fuel generosity. Two mechanisms might be important. High employment rates fuel demand for social insurance, not only because it is a normal good (Barth and Moene 2011) but also because it becomes cheaper. The fewer people that need to use the system, relative to the employed population, the less expensive it is per employed to provide the taxes necessary for higher generosity.

Finally, we have also shown that countries with more egalitarian wage structure tend to have lower unemployment, in several cases, even low relative unemployment for the low wage groups. As hinted to one important reason might be coordination in bargaining combined with active labor market measures. Wage coordination leads to both wage compression and low unemployment. The reason is likely to be that coordination in bargaining internalizes externalities across complements in production.

Features like these were much more discussed in the 1980s and were made famous in the book by Layard et al. (1991). Ten years later, even the OECD (2006) recognizes the positive unemployment performance of countries with a combination of coordinated bargaining and active labor market policies. Perhaps we now will see a revival of the emphasis of these arrangements as a system of risk sharing that spreads the costs of international fluctuations to the whole labor market?

\section{Acknowledgments}

This project is part of the work at ESOP at the Department of Economics, University of Oslo. ESOP is financed by the Norwegian Research Council. We also acknowledge support from project \#199836 (TREfF) at the Norwegian Research Council.

\section{Appendix I Data}

\begin{tabular}{|c|c|c|c|c|c|}
\hline & All covariates & $\begin{array}{l}\text { Generosity and } \\
\text { Coord. }\end{array}$ & & Wage inequality & \\
\hline & Sample I & Sample 2 & $\begin{array}{l}\text { OECD Empl. } \\
\text { Outlook } 96\end{array}$ & $\mathrm{ECHP}$ & $\begin{array}{l}\text { OECD earnings } \\
\text { database }\end{array}$ \\
\hline Australia & | 997-2007 & 1997-2002 & & & 1997-2007 \\
\hline Austria & $\begin{array}{l}\text { |994-200|, } \\
2004-2007\end{array}$ & |994-200| & 1994 & |995-200| & 2004-2007 \\
\hline Belgium & $\begin{array}{l}\text { |985-1993, } \\
\text { 1995-2007 }\end{array}$ & $\begin{array}{l}\text { 1985-1993, } \\
\text { 1995-2002 }\end{array}$ & |985-|993 & |994-200| & 1999-2007 \\
\hline
\end{tabular}




\begin{tabular}{|c|c|c|c|c|c|}
\hline Canada & $\begin{array}{l}1991-1994 \\
1997-2007\end{array}$ & $\begin{array}{l}\text { |99|-1994, } \\
\text { |997-2002 }\end{array}$ & $1991-1994$ & & 1997-2007 \\
\hline $\begin{array}{l}\text { Czech } \\
\text { Republic }\end{array}$ & 1997-2007 & & & & | 997-2007 \\
\hline Denmark & $\begin{array}{l}\text { 1986-1990, } \\
\text { 1995-2007 }\end{array}$ & $\begin{array}{l}\text { 1986-1990, } \\
\text { 1995-2002 }\end{array}$ & & |994-200| & $\begin{array}{l}\text { 1986-1990, } \\
\text { 1996-2007 }\end{array}$ \\
\hline Finland & 1986-2007 & 1986-2002 & & |996-200| & 1986-2007 \\
\hline France & 1994-2007 & 1994-2002 & & |994-200| & 1994-2007 \\
\hline Germany & $|99|-2007$ & $|99|-2002$ & & & |99|-2007 \\
\hline Greece & 1994-1997 & . & & |994-200| & 2004-2007 \\
\hline Italy & 2004-2007 & . & & & 2004-2007 \\
\hline Japan & 1990-2007 & 1990-2002 & & & 1990-2007 \\
\hline Korea & $2000-2007$ & . & & & 2000-2007 \\
\hline New Zealand & 1994-2007 & . & & & 1994-2007 \\
\hline Norway & $\begin{array}{l}\text { 1991, 1997- } \\
2007\end{array}$ & $\begin{array}{l}\text { |991, | 1997- } \\
2002\end{array}$ & 1991 & & | 997-2007 \\
\hline Poland & 1997, 2007 & . & & & 1997-2007 \\
\hline Portugal & $\begin{array}{l}\text { 1985, } 1989 \\
\text { 1991-2001, } \\
2004-2007\end{array}$ & . & $\begin{array}{l}\mid 985,1989 \\
|99|-200 \mid\end{array}$ & |994-200| & 2004-2007 \\
\hline Spain & $\begin{array}{l}\text { 1994-2001, } \\
2002,2004- \\
2007\end{array}$ & . & & |994-200| & $\begin{array}{l}1995,2002 \\
2004-2007\end{array}$ \\
\hline Sweden & 1985-2007 & 1985-2002 & & & $\begin{array}{l}\text { 1985-2004, } \\
1990-2007\end{array}$ \\
\hline Switzerland & $\begin{array}{l}1996,1998 \\
2000,2002, \\
2006\end{array}$ & $\begin{array}{l}\text { 1996, 1998, } \\
2000,2002\end{array}$ & & & $\begin{array}{l}1996,1998 \\
2000,2002 \\
2006\end{array}$ \\
\hline $\begin{array}{l}\text { United } \\
\text { Kingdom }\end{array}$ & 1985-2007 & 1985-2002 & & & 1985-2007 \\
\hline United States & | 985-2007 & 1985-2002 & & & | 985-2007 \\
\hline
\end{tabular}

Note: country not included in Sample 2.

Employment and labor force participation are defined in percent of population in the relevant age group. Unemployment rate is defined as percent of labor force in relevant age group. Data from the OECD Labor Force Statistics, 1985-2007, extracted from the OECD iLibrary.

Wage inequality is defined as $\mathrm{d} 9 / \mathrm{d} 1$ of gross hourly wage and is for the most part taken from the OECD earnings database, extracted from the OECD ilibrary. Additional data are from the OECD Employment Outlook 1996 (1985-1994) and from ECHP (1995-2001). See Table A1 for details. Indicator variables are included in the analysis to control for data source when data are taken from ECHP (including a time 
Table A I Employment-population rates, by gender and age group, percent 2007.

\begin{tabular}{|c|c|c|c|c|c|}
\hline & & & & Women & Men \\
\hline Country & $\begin{array}{l}15-64 \\
\text { years }\end{array}$ & $\begin{array}{l}15-24 \\
\text { years }\end{array}$ & $\begin{array}{l}55-64 \\
\text { years }\end{array}$ & $\begin{array}{l}25-54 \\
\text { years }\end{array}$ & $\begin{array}{l}25-54 \\
\text { years }\end{array}$ \\
\hline Iceland & 85.7 & 74.3 & 84.9 & 84.1 & 94.2 \\
\hline Switzerland & 78.6 & 62.6 & 67.2 & 78.5 & 93.6 \\
\hline Denmark & 77.1 & 65.3 & 58.6 & 82.4 & 90.2 \\
\hline Norway & 76.9 & 55.1 & 69.0 & 82.3 & 89.2 \\
\hline Sweden & 75.7 & 46.3 & 70.1 & 83.0 & 89.0 \\
\hline New Zealand & 75.2 & 58.2 & 71.8 & 74.3 & 90.1 \\
\hline The Netherlands & 74.8 & 68.2 & 48.3 & 77.6 & 91.3 \\
\hline Canada & 73.6 & 59.5 & 57.1 & 78.2 & 86.2 \\
\hline Australia & 72.8 & 64.1 & 56.6 & 71.9 & 88.1 \\
\hline United Kingdom & 72.3 & 55.9 & 57.4 & 74.7 & 88.3 \\
\hline United States & 71.8 & 53.1 & 61.8 & 72.5 & 87.5 \\
\hline Austria & 71.4 & 55.5 & 38.6 & 77.5 & 90.6 \\
\hline Japan & 70.7 & 41.4 & 66.1 & 67.4 & 92.8 \\
\hline Finland & 70.5 & 46.4 & 55.0 & 80.7 & 85.9 \\
\hline G7 countries & 69.7 & 46.9 & 56.7 & 71.5 & 88.3 \\
\hline North America & 69.4 & 50.8 & 60.3 & 67.9 & 88.5 \\
\hline Estonia & 69.4 & 34.5 & 60.0 & 80.1 & 89.7 \\
\hline Oceania & 69.3 & 40.7 & 64.4 & 66.1 & 90.7 \\
\hline Ireland & 69.2 & 49.8 & 54.2 & 69.6 & 87.8 \\
\hline Germany & 69.0 & 45.9 & 51.3 & 74.0 & 86.4 \\
\hline Russian Federation & 68.1 & 34.8 & 48.4 & 82.2 & 86.7 \\
\hline Portugal & 67.8 & 34.9 & 50.9 & 74.9 & 87.2 \\
\hline Slovenia & 67.8 & 37.6 & 33.5 & 82.4 & 88.1 \\
\hline European Union 15 & 67.0 & 41.6 & 46.4 & 71.3 & 87.8 \\
\hline Spain & 66.6 & 42.9 & 44.6 & 65.6 & 87.6 \\
\hline OECD countries & 66.5 & 43.2 & 53.5 & 66.3 & 88.0 \\
\hline Czech Republic & 66.1 & 28.5 & 46.0 & 74.9 & 91.7 \\
\hline European Union 19 & 65.8 & 38.9 & 44.6 & 71.1 & 87.2 \\
\hline Luxemburg & 64.2 & 22.5 & 32.0 & 71.7 & 92.2 \\
\hline France & 64.0 & 30.1 & 38.3 & 76.1 & 88.3 \\
\hline Korea & 63.9 & 25.7 & 60.6 & 60.5 & 87.3 \\
\hline Europe & 63.4 & 37.9 & 43.8 & 65.5 & 86.4 \\
\hline
\end{tabular}




\begin{tabular}{llllll}
\hline Belgium & 62.0 & 27.5 & 34.4 & 72.3 & 87.0 \\
\hline Greece & 61.4 & 24.0 & 42.4 & 60.8 & 90.1 \\
\hline Mexico & 61.1 & 44.2 & 54.7 & 51.0 & 92.9 \\
\hline Slovak Republic & 60.7 & 27.6 & 35.7 & 71.0 & 85.0 \\
\hline Israel & 58.9 & 27.2 & 57.2 & 67.1 & 78.9 \\
\hline Italy & 58.7 & 24.7 & 33.8 & 59.6 & 87.3 \\
\hline Hungary & 57.3 & 21.0 & 33.1 & 67.9 & 81.3 \\
\hline Poland & 57.0 & 25.8 & 29.7 & 68.8 & 81.1 \\
\hline Chile & 56.3 & 26.4 & 54.4 & 50.6 & 89.0 \\
\hline Turkey & 44.6 & 30.2 & 27.1 & 25.6 & 80.7 \\
\hline
\end{tabular}

Source: OECD Labor Force Statistics, extracted from the OECD ilibrary. Sorted by employment population ratio I5-64 years.

interaction), for Austria, Greece, and Portugal before 2002 and for annual data when reported.

Generosity of the welfare state is measured by the overall generosity index provided in the Comparative Welfare Entitlements Dataset, constructed and generously made available for other researchers by Lyle Scruggs at the University of Connecticut. The index captures the generosity of income support in the case of illness, of unemployment, and of disability pensions (including old age) of each country year cell. Generosity is constructed using the replacement ratio, coverage, entitlements, and timing of different schemes, in addition to other features of the schemes. The construction of the index is described in Scruggs (2004, 2007). The data set is available at http://sp.uconn.edu/ scruggs/wp.htm

Coordination in bargaining is defined as the 10-year average of (present and lagged) bargaining level 2 from Golden et al. (2006). Bargaining level 2 is the level at which wages are determined, coded as follows (2001-2002 values of bargaining level 2 are set at 2000 values):

$1=$ plant-level wage setting

2 = industry-level wage setting without sanctions

$3=$ industry-level wage setting with sanctions

$4=$ central wage setting without sanctions

5 = central wage setting with sanctions

Tax wedge is calculated for one-earner married couple at average earnings, 2 children, and is taken from the OECD Taxation Data, historical rates 1985-2004, comparative tables 2005-2007, extracted from the OECD iLibrary. When historical rates report data every other year, the average is used for the year in between. Differences between the two series (historical rates and comparative rates) are adjusted using the ratio of the average reported rate from each source for the overlapping years 2000-2004 for each country. Public expenditure on labor-marked programs is taken from the OECD Labor Market Programs DataBase, 1985-2007, extracted from the OECD ilibrary. Union density is taken from the OECD Trade Union Data, 1985-2007, extracted 
from the OECD ilibrary. The percent of population with tertiary education from 1990 to 2007 is taken from the OECD Education at a Glance, various years (linearized when missing and for 2007). From 1985 to 1989, education data are imputed using linearized values of five years figures reported in De la Fuente and Domenech (2002). Employment protection is defined as Overall employment protection legislation index, version 1, 1985-2007, extracted from the OECD ilibrary. Public social expenditure is defined as total social public spending per capita and is taken from the OECD Social expenditure database, 1985-2007, extracted from the OECD ilibrary.

Table A2 Employment population rates, by educational group, percent 2007.

\begin{tabular}{|c|c|c|c|c|}
\hline & & & & Ratio \\
\hline Country & $\begin{array}{l}\text { Below upper } \\
\text { secondary }\end{array}$ & Upper secondary & Tertiary & Below/Tertiary \\
\hline Iceland & 84.1 & 88.6 & 92.2 & 0.91 \\
\hline Switzerland & 66.0 & 81.1 & 90.0 & 0.73 \\
\hline Denmark & 66.6 & 82.5 & 87.8 & 0.76 \\
\hline Norway & 66.3 & 84.0 & 90.4 & 0.73 \\
\hline Sweden & 66.6 & 83.1 & 88.6 & 0.75 \\
\hline New Zealand & 71.0 & 84.6 & 83.7 & 0.85 \\
\hline The Netherlands & 61.9 & 80.3 & 87.7 & 0.71 \\
\hline Canada & 57.3 & 76.5 & 82.9 & 0.69 \\
\hline Australia & 63.9 & 80.5 & 84.8 & 0.75 \\
\hline United Kingdom & 64.9 & 80.9 & 87.8 & 0.74 \\
\hline United States & 58.3 & 73.6 & 83.3 & 0.70 \\
\hline Austria & 57.9 & 76.9 & 86.8 & 0.67 \\
\hline Japan & & 74.4 & 80.1 & \\
\hline Finland & 58.6 & 76.2 & 85.2 & 0.69 \\
\hline Ireland & 58.7 & 77.1 & 86.7 & 0.68 \\
\hline Germany & 54.6 & 74.4 & 85.5 & 0.64 \\
\hline Portugal & 71.6 & 79.8 & 85.9 & 0.83 \\
\hline Spain & 60.5 & 76.3 & 84.4 & 0.72 \\
\hline Czech Republic & 45.7 & 76.1 & 85.2 & 0.54 \\
\hline Luxemburg & 62.3 & 73.9 & 84.5 & 0.74 \\
\hline France & 57.8 & 75.8 & 83.5 & 0.69 \\
\hline Korea & 66.0 & 70.7 & 77.2 & 0.86 \\
\hline Belgium & 49.8 & 74.2 & 84.9 & 0.59 \\
\hline Greece & 59.9 & 69.4 & 82.6 & 0.73 \\
\hline
\end{tabular}




\begin{tabular}{lllll}
\hline Mexico & 63.0 & 73.5 & 83.0 & 0.76 \\
\hline Slovak Republic & 29.1 & 73.2 & 84.2 & 0.35 \\
\hline Italy & 52.8 & 74.5 & 80.2 & 0.66 \\
\hline Hungary & 38.5 & 70.2 & 80.4 & 0.48 \\
\hline Poland & 41.0 & 65.2 & 84.5 & 0.49 \\
\hline Turkey & 46.9 & 61.0 & 74.6 & 0.63 \\
\hline
\end{tabular}

Source: OECD Factbook 201 I: Economic, Environmental and Social Statistics - OECDAge group 25-64 years. Sorted by employment population ratio 15-64 years (Table I).

Table A3 Labor force participation rates, percent 2007.

\begin{tabular}{lccccc}
\hline Country & \multicolumn{1}{c}{$\begin{array}{l}\text { 15-24 } \\
\text { years }\end{array}$} & $\begin{array}{c}55-64 \\
\text { years }\end{array}$ & $\begin{array}{c}25-54 \\
\text { years }\end{array}$ & $\begin{array}{c}25-54 \\
\text { years }\end{array}$ \\
\hline Iceland & 87.8 & 80.1 & 85.7 & 85.4 & 95.3 \\
\hline Switzerland & 81.6 & 67.4 & 69.3 & 81.9 & 95.8 \\
\hline Sweden & 80.6 & 57.1 & 73.0 & 87.1 & 92.9 \\
\hline Denmark & 80.2 & 70.9 & 60.8 & 85.4 & 92.5 \\
\hline Norway & 78.9 & 59.4 & 69.7 & 84.0 & 90.9 \\
\hline Canada & 78.4 & 67.0 & 60.1 & 82.1 & 91.1 \\
\hline New Zealand & 78.1 & 64.7 & 72.9 & 76.6 & 92.1 \\
\hline The Netherlands & 77.5 & 72.8 & 50.4 & 80.3 & 93.3 \\
\hline United Kingdom & 76.3 & 65.3 & 59.3 & 77.6 & 91.6 \\
\hline Australia & 76.2 & 70.8 & 58.2 & 74.8 & 90.8 \\
\hline Finland & 75.7 & 55.0 & 58.8 & 85.6 & 90.3 \\
\hline Germany & 75.6 & 52.0 & 57.2 & 80.6 & 93.8 \\
\hline United States & 75.3 & 59.4 & 63.8 & 75.4 & 90.9 \\
\hline Austria & 74.7 & 60.8 & 39.8 & 81.1 & 93.7 \\
\hline Portugal & 74.1 & 41.9 & 54.4 & 82.8 & 92.8 \\
\hline G7 countries & 73.7 & 53.1 & 59.2 & 75.2 & 92.5 \\
\hline Japan & 73.6 & 44.9 & 68.4 & 70.1 & 96.3 \\
\hline Estonia & 72.9 & 38.3 & 62.2 & 83.7 & 93.6 \\
\hline North America & 72.7 & 56.1 & 62.2 & 70.5 & 91.8 \\
\hline Ireland & 72.6 & 55.4 & 55.4 & 72.2 & 91.6 \\
\hline Spain & 72.6 & 52.4 & 47.4 & 72.7 & 92.6 \\
\hline Russian Federation & 72.5 & 40.6 & 49.9 & 86.4 & 91.6 \\
\hline European Union 15 & 72.1 & 48.8 & 49.2 & 76.7 & 92.8 \\
\hline & & & & & \\
\hline
\end{tabular}




\begin{tabular}{llllll}
\hline Oceania & 72.1 & 44.4 & 66.5 & 68.5 & 94.0 \\
\hline Slovenia & 71.3 & 41.8 & 34.6 & 87.3 & 91.3 \\
\hline European Union 19 & 71.0 & 46.0 & 47.3 & 76.7 & 92.3 \\
\hline OECD countries & 70.6 & 49.1 & 55.7 & 70.0 & 92.2 \\
\hline Czech Republic & 69.8 & 31.9 & 48.2 & 80.3 & 95.0 \\
\hline France & 69.5 & 37.0 & 40.4 & 82.4 & 94.2 \\
\hline Europe & 68.5 & 45.0 & 46.4 & 70.6 & 91.8 \\
\hline Slovak Republic & 68.2 & 34.5 & 38.8 & 80.5 & 93.0 \\
\hline Belgium & 67.1 & 33.9 & 35.9 & 78.0 & 92.5 \\
\hline Greece & 67.0 & 31.1 & 43.9 & 69.1 & 94.6 \\
\hline Luxemburg & 66.9 & 26.5 & 32.7 & 74.7 & 94.9 \\
\hline Korea & 66.2 & 28.2 & 62.0 & 62.0 & 90.5 \\
\hline Israel & 63.7 & 32.4 & 60.4 & 72.0 & 83.7 \\
\hline Mexico & 63.3 & 47.4 & 55.6 & 52.6 & 95.3 \\
\hline Poland & 63.2 & 33.0 & 31.8 & 75.6 & 87.9 \\
\hline Italy & 62.5 & 30.9 & 34.6 & 64.1 & 91.0 \\
\hline Hungary & 61.9 & 25.6 & 34.5 & 73.2 & 86.9 \\
\hline Chile & 60.8 & 32.1 & 56.5 & 54.6 & 93.9 \\
\hline Turkey & 49.8 & 37.7 & 28.3 & 28.0 & 88.1 \\
\hline Source:CE & & & 56 & & \\
\hline
\end{tabular}

Source: OECD Labor Force Statistics, extracted from the OECD ilibrary. Sorted by labor force participation rates I5-64 years.

Table A4 Unemployment rates, percent 2007.

\begin{tabular}{lccccc}
\hline Country & $\begin{array}{c}15-64 \\
\text { years }\end{array}$ & $\begin{array}{c}15-24 \\
\text { years }\end{array}$ & $\begin{array}{c}55-64 \\
\text { years }\end{array}$ & $\begin{array}{c}25-54 \\
\text { years }\end{array}$ & $\begin{array}{c}25-54 \\
\text { years }\end{array}$ \\
\hline Iceland & 2.3 & 7.2 & 0.9 & 1.6 & 1.2 \\
\hline Norway & 2.6 & 7.3 & 1.0 & 2.0 & 1.9 \\
\hline Korea & 3.4 & 8.8 & 2.2 & 2.4 & 3.6 \\
\hline The Netherlands & 3.5 & 6.3 & 4.2 & 3.4 & 2.1 \\
\hline Mexico & 3.5 & 6.7 & 1.6 & 3.1 & 2.5 \\
\hline Switzerland & 3.7 & 7.1 & 3.1 & 4.1 & 2.3 \\
\hline New Zealand & 3.8 & 10.1 & 1.5 & 3.0 & 2.2 \\
\hline Denmark & 3.8 & 7.9 & 3.5 & 3.5 & 2.6 \\
\hline Oceania & 3.9 & 8.3 & 3.1 & 3.5 & 3.5 \\
\hline Japan & 4.1 & 7.7 & 3.4 & 3.9 & 3.6 \\
\hline
\end{tabular}




\begin{tabular}{|c|c|c|c|c|c|}
\hline Luxemburg & 4.1 & 15.2 & 2.1 & 4.0 & 2.8 \\
\hline Australia & 4.4 & 9.4 & 2.7 & 3.9 & 2.9 \\
\hline Austria & 4.5 & 8.7 & 3.0 & 4.5 & 3.3 \\
\hline North America & 4.6 & 9.6 & 3.0 & 3.8 & 3.6 \\
\hline United States & 4.7 & 10.5 & 3.1 & 3.8 & 3.7 \\
\hline Ireland & 4.7 & 10.0 & 2.2 & 3.6 & 4.2 \\
\hline Estonia & 4.8 & 10.0 & 3.5 & 4.3 & 4.2 \\
\hline Slovenia & 5.0 & 10.1 & 3.3 & 5.6 & 3.4 \\
\hline United Kingdom & 5.3 & 14.4 & 3.3 & 3.7 & 3.7 \\
\hline Czech Republic & 5.4 & 10.7 & 4.6 & 6.7 & 3.5 \\
\hline G7 countries & 5.5 & 11.6 & 4.1 & 5.0 & 4.5 \\
\hline OECD countries & 5.8 & 12.0 & 4.0 & 5.3 & 4.6 \\
\hline Canada & 6.1 & 11.2 & 5.0 & 4.7 & 5.3 \\
\hline Russian Federation & 6.1 & 14.4 & 3.0 & 4.9 & 5.4 \\
\hline Sweden & 6.2 & 18.9 & 3.9 & 4.7 & 4.1 \\
\hline Italy & 6.2 & 20.3 & 2.4 & 7.1 & 4.0 \\
\hline Finland & 6.9 & 15.7 & 6.5 & 5.8 & 4.8 \\
\hline European Union 15 & 7.1 & 14.8 & 5.7 & 7.0 & 5.4 \\
\hline European Union 19 & 7.3 & 15.4 & 5.7 & 7.3 & 5.6 \\
\hline Chile & 7.4 & 17.8 & 3.8 & 7.3 & 5.2 \\
\hline Israel & 7.4 & 16.1 & 5.3 & 6.8 & 5.7 \\
\hline Hungary & 7.4 & 18.0 & 4.2 & 7.2 & 6.5 \\
\hline Europe & 7.5 & 15.8 & 5.5 & 7.2 & 5.8 \\
\hline Belgium & 7.5 & 18.8 & 4.2 & 7.4 & 5.9 \\
\hline France & 8.0 & 18.7 & 5.1 & 7.7 & 6.3 \\
\hline Spain & 8.3 & 18.2 & 5.9 & 9.7 & 5.4 \\
\hline Greece & 8.4 & 22.9 & 3.4 & 12.0 & 4.7 \\
\hline Portugal & 8.5 & 16.6 & 6.5 & 9.6 & 6.1 \\
\hline Germany & 8.7 & 11.7 & 10.3 & 8.1 & 7.8 \\
\hline Poland & 9.7 & 21.7 & 6.8 & 9.1 & 7.8 \\
\hline Turkey & 10.5 & 20.0 & 4.3 & 8.8 & 8.5 \\
\hline Slovak Republic & 11.0 & 20.1 & 8.1 & 11.9 & 8.6 \\
\hline
\end{tabular}

Source: OECD Labor Force Statistics, extracted from the OECD ilibrary. Sorted by unemployment rate 15-64 years. 
Table A5 Unemployment rates, by educational group, percent 2007.

\begin{tabular}{|c|c|c|c|c|}
\hline Country & Below upper secondary & Upper secondary & Tertiary & Below/Tertiary ratio \\
\hline Norway & 3.3 & 1.3 & 1.4 & 2.33 \\
\hline Korea & 2.4 & 3.3 & 2.9 & 0.81 \\
\hline The Netherlands & 4.0 & 2.7 & 1.8 & 2.25 \\
\hline Mexico & 2.2 & 2.8 & 3.6 & 0.62 \\
\hline Switzerland & 6.7 & 3.0 & 2.1 & 3.17 \\
\hline New Zealand & 3.1 & 2.0 & 2.2 & 1.39 \\
\hline Denmark & 4.2 & 2.5 & 2.9 & 1.42 \\
\hline Japan & & 4.1 & 2.9 & \\
\hline Luxemburg & 4.1 & 2.8 & 3.0 & 1.39 \\
\hline Australia & 5.1 & 3.0 & 2.2 & 2.31 \\
\hline Austria & 7.4 & 3.3 & 2.4 & 3.10 \\
\hline United States & 8.5 & 4.5 & 2.1 & 4.01 \\
\hline Ireland & 6.1 & 3.5 & 2.3 & 2.64 \\
\hline United Kingdom & 6.5 & 3.9 & 2.3 & 2.86 \\
\hline Canada & 9.5 & 5.4 & 3.9 & 2.46 \\
\hline Sweden & 7.0 & 4.2 & 3.4 & 2.07 \\
\hline Italy & 6.3 & 4.1 & 4.2 & 1.51 \\
\hline Finland & 8.9 & 6.1 & 3.6 & 2.49 \\
\hline Hungary & 16.0 & 5.9 & 2.6 & 6.26 \\
\hline Belgium & 11.3 & 6.2 & 3.3 & 3.44 \\
\hline France & 10.2 & 6.0 & 4.9 & 2.11 \\
\hline Spain & 9.0 & 6.8 & 4.8 & 1.87 \\
\hline Greece & 7.0 & 8.2 & 6.1 & 1.16 \\
\hline Portugal & 8.0 & 6.8 & 6.6 & 1.21 \\
\hline Germany & 18.0 & 8.3 & 3.8 & 4.69 \\
\hline Poland & 15.5 & 8.7 & 3.8 & 4.05 \\
\hline Turkey & 8.6 & 9.1 & 6.8 & 1.26 \\
\hline Slovak Republic & 41.3 & 8.5 & 3.3 & 12.59 \\
\hline
\end{tabular}

Source: OECD Factbook 20 I0: Economic, Environmental and Social Statistics - OECD. Age group 25-64 years. Sorted by unemployment rate 15-64 years. 


\section{References}

Barth, Erling and Karl Ove Moene (2011) “The Equality Multiplier”. ESOP working paper, University of Oslo.

Blau, Francine D. \& Lawrence M. Kahn (2005) "Do Cognitive Test Scores Explain Higher U.S. Wage Inequality?,” The Review of Economics and Statistics 87(1): 184-193, MIT Press.

Calmfors, Lars and J. Driffill (1988) "Bargaining Structure, Corporatism and Macroeconomic Performance," Economic Policy 6: 13-62.

Card, David and Alan B. Krueger (1995) Myth and Measurement: The New Economics of the Minimum Wage. Princeton, NJ: Princeton University Press.

De la Fuente Angel and Rafael Domenech (2006) "Human Capital in Growth Regressions: How Much Difference Does Data Quality Make?," Journal of the European Economic Association 4(1): 1-36.

Faggio, Guilia and Stephen Nickell (2006) "Patterns of Work Across the OECD" CEPR discussion paper \#730.

Freeman, Richard (1988) "Labour Market Institutions and Economic Performance," Economic Policy 3: 64-80.

Freeman, Richard and James Medoff (1984) What Do Unions Do? New York: Basic Books.

Golden, Miriam, Peter Lange, and Michael Wallerstein (2006) "Union Centralization among Advanced Industrial Societies: An Empirical Study." Dataset available at http://www.shelley.polisci.ucla.edu/

Layard, Nickell and Jackman (1991) Unemployment. Oxford: Oxford University Press.

Manning, Alan (2003) Monopsony in Motion, Imperfect Competition in Labor Markets. Princeton, NJ: Princeton University Press.

Moene, Karl Ove \& Wallerstein, Michael, (1997) "Pay Inequality," Journal of Labor Economics, University of Chicago Press, vol. 15(3), pages 403-30, July

Moene, K. O., Michael Wallerstein, and Michael Hoel (1993) "Bargaining Structure and Economic Performance" in Flanagan, Moene and Wallerstein (eds) Trade Union Behaviour, Pay Bargaining and Economic Performance. Oxford: Clarendon Press.

Nickell, Stephen, Luca Nunciata, and Wolfgang Ochel (2005) "Unemployment in the OECD since the 1960s. What do we know?," The Economic Journal 115: 1-27.

OECD (2006) Employment Outlook 2006.

OECD (2010) Sickness, Disability and Work: Breaking the Barriers: A Synthesis of Findings across OECD Countries. Paris: OECD Publishing. 